\title{
Bibliometric description of the literature on HTLV- 1 registered in PubMed over the past ten years
}

\author{
Kristien Verdonck ${ }^{1,2^{*}}$, Eduardo Gotuzzo ${ }^{1}$ \\ From 15th International Conference on Human Retroviruses: HTLV and Related Viruses \\ Leuven and Gembloux, Belgium. 5-8 June 2011
}

\section{Introduction}

We conducted a bibliometric evaluation to get insight into research activities and tendencies.

\section{Methods}

The search criteria in PubMed were: (1) "human T-lymphotropic virus 1" as medical subject headings (MeSH) major topic; and (2) publication date from January 2001-December 2010. We retrieved publication year, author names, journal, country of first author, language, free availability, and MeSH terms.

\section{Results}

The search retrieved 1189 publications by 3969 authors. Twenty-eight authors published $>=15$ articles. The number of publications did not increase: 600 in 2001-2005 and 589 in 2006-2010. The journals with the highest number of publications are: Journal of virology (126), Retrovirology (58), Blood (47), The Journal of biological chemistry (45) and Virology (41). In 349 publications (30\%), the first author was from the USA; Japan contributed 329 publications (28\%); Brazil 115 (10\%); France 91 (8\%); and the UK 54 (5\%). The proportion of publications with a first author from Latin America or the Caribbean increased over time (10\% in $2001-2002$; $18 \%$ in 2009-2010); the proportion with a North American first author decreased (34\% in 2001-2002; $26 \%$ in 20092010). Ninety-six percent (1137) of the publications are in English. The full text of 582 publications (49\%) is freely available. The most frequent $\mathrm{MeSH}$ terms relate to virology. Clinical/epidemiological $\mathrm{MeSH}$ terms are more frequent in publications from Latin America and the Caribbean than elsewhere.

\footnotetext{
* Correspondence: t_verdonck@yahoo.com

'Instituto de Medicina Tropical Alexander von Humboldt, Universidad

Peruana Cayetano Heredia, Lima, Peru

Full list of author information is available at the end of the article
}

\section{Conclusions}

The constantly modest number of publications characterizes HTLV-1 as a neglected health problem. The $\mathrm{MeSH}$ terms suggest that clinical/epidemiological aspects are investigated much less frequently than virological aspects.

\section{Author details}

${ }^{1}$ Instituto de Medicina Tropical Alexander von Humboldt, Universidad Peruana Cayetano Heredia, Lima, Peru. ${ }^{2}$ Institute of Tropical Medicine, Antwerp, Belgium.

Published: 6 June 2011

\section{doi:10.1186/1742-4690-8-S1-A247}

Cite this article as: Verdonck and Gotuzzo: Bibliometric description of the literature on HTLV-1 registered in PubMed over the past ten years. Retrovirology 2011 8(Suppl 1):A247.
Submit your next manuscript to BioMed Central and take full advantage of:

- Convenient online submission

- Thorough peer review

- No space constraints or color figure charges

- Immediate publication on acceptance

- Inclusion in PubMed, CAS, Scopus and Google Scholar

- Research which is freely available for redistribution
() Biomed Central

\section{() Biomed Central}

